\title{
Politics of Last Resort
}

\author{
Governing by Emergency \\ in the European Union
}

Jonathan White (LSE)

Oxford University Press, December 2019 


\section{Contents}

Acknowledgements

Introduction

1. Beyond a Sovereign State of Exception

2. Structural Vulnerabilities of the Transnational Sphere

3. Towards Emergency Europe

4. Prospects of a New Normal

5. Iterations of Technocracy

6. Populism as the Promise of Agency

7. Principled Disobedience

8. Structuring Partisan Power

9. Beyond a Politics of Singularities 


\section{Acknowledgements}

The book has benefitted immensely from the input of others. Some read large chunks in draft form: I am deeply grateful to Carlo Invernizzi Accetti, Waltraud Schelkle, Jan Suntrup, and Lea Ypi for their willingness to devote time and offer valuable suggestions. Others encountered the argument at workshops and seminars, and for their comments I would particularly like to thank the following: Bruce Ackerman, Štefan Auer, Marija Bartl, Olivier Beaud, Richard Bellamy, Vojtěch Belling, Chris Bickerton, Jacco Bomhoff, Hauke Brunkhorst, Dario Castiglione, Damian Chalmers, Ben Crum, Deirdre Curtin, Marco Dani, Mark Dawson, Pieter de Wilde, Dimitris Efthymiou, Erik Oddvar Eriksen, John Erik Fossum, Simon Glendinning, Sverker Gustavsson, Lise Herman, Josef Hien, Sara Hobolt, Jonathan Hopkin, Achim Hurrelmann, Daniel Innerarity, Abby Innes, Giulio Itzcovich, Christian Joerges, Andreas Kalyvas, Lucy Kinski, Mareike Kleine, Satoshi Kodama, Jan Komárek, Christian KreuderSonnen, Joseph Lacey, Christopher Lord, Philip Manow, Agustín Menéndez, Benjamin Moffitt, Glyn Morgan, Jan-Werner Müller, Kalypso Nicolaidis, Pieter Niesen, Claus Offe, Markus Patberg, Anne Phillips, Sonja Puntscher Riekmann, Mark Salter, Bill Scheuerman, Nicole Scicluna, Astrid Séville, Alexander Somek, Antoine Vauchez, Albert Weale, Frank Wendler, Mike Wilkinson, Fabio Wolkenstein, and David Woodruff. I also benefitted greatly from two outstanding $\mathrm{PhD}$ researchers working on related topics in this period: Hjalte Lokdam and Marta Lorimer.

The idea for the book emerged in 2012, when writing what would later be published as 'Emergency Europe' in Political Studies. The article was given the journal's 2015 Harrison Prize for best paper, and I am very grateful to the editors and jury for the encouragement to go further into the topic. Most of the writing for the book was done based at my usual academic home, the LSE's European Institute. I thank staff and students for making it a friendly and stimulating environment. I would also like to acknowledge the Wissenschaftskolleg zu Berlin, where ideas were developed during a one-year fellowship in 2014-15 funded by the EURIAS Foundation, and the Europe Center at Stanford University, where a chapter was written during a fellowship in spring 2017.

At Oxford University Press I would like to thank Dominic Byatt, as well as three anonymous reviewers. Two chapters draw on previously published material, and I acknowledge Wiley for permission to reproduce passages from the following: 'Principled Disobedience in the EU', Constellations 24 (4), 2017; and 'Authority after Emergency Rule', Modern Law Review 78 (4), 2015.

Family life with three young children is a good way to get thinking about permanent states of emergency. Sharing an increasingly noisy house with Arbien, Rubin, and Hana has been a source of pleasure and inspiration. I am very grateful to them in countless ways, as I am to my mother Ann and my late father John. In particular I would like to thank Lea, for her conversation, love, sacrifices, and support. 


\title{
Introduction
}

\begin{abstract}
'The challenges of recent years forced national governments and EU institutions to take quick and extraordinary steps. They needed to stabilise their economies and to protect all that has been achieved through the gradual and at times painstaking process of European integration. As a result, the integrity of the euro area as a whole has been preserved and the internal market remains strong. ... Europe's Economic and Monetary Union (EMU) today is like a house that was built over decades but only partially finished. When the storm hit, its walls and roof had to be stabilised quickly. It is now high time to reinforce its foundations ...'
\end{abstract}

The 'Five Presidents' Report', European Commission (2015), p.4.

When the art of governing is cast as the taming of extreme natural forces, decision-making predictably resembles the management of an emergency. From storms in the economy to waves of migration, themes of freakish weather are part of the vernacular of modern politics. As some officials battle the elements, others contend with gravity or infection: markets risk collapse, currencies and confidence plummet, and contagion breaks out. Authorities claim the need to act fast and decisively. 'Quick and extraordinary steps' aim to stabilise the situation, containing what threatens to become uncontainable. Then come the preparations for things yet to happen: foundations are reinforced, defences mended, shock absorbers installed. With some intensity in the 2010s, Europe's executive powers came to embrace this way of governing, with actions departing from convention rationalised as necessary responses to exceptional and urgent threats.

Looking back on developments in Europe over the last decade and more, frenetic activity and the improvisation of new arrangements are some of the dominant themes. The European Union (EU) has undergone great change. Interventions by national and European executives to control money and people have left a legacy of new institutions that continues to expand. From economic monitoring to border policing, one sees new formations spanning the national and supranational that reconfigure how decisions are made and enforced. Introduced and maintained in the name of crisis response, these structures well exceed what was envisioned in prior formalisations of the EU system, and challenge the norms of national politics too.

And yet, while the institutional scene has been in persistent flux, the substance of policy and the contours of social power look more constant. As many accounts on the theme of the 'strange non-death of neoliberalism' suggest, the basics of the economic order have been slow to change. Principles of low deficit, low spending and competition continue to be embraced as the foundation for public policy, while the prioritisation of debt repayment continues to be axiomatic. Border regimes continue to be geared to an idea of fortress Europe, now pursued more stringently. In some ways the capacity to contest these priorities seems more limited than ever, 
as policies are embedded in the very logic of new institutions and as quasi-constitutional commitments. Changing course is made harder by the notion that renegotiating these policies would re-open the conditions of crisis they were meant to contain. The institutional landscape has been transformed, but broadly in the service of the existing socio-economic order. Extraordinary action has been for the sake of preservation, restoration, extension.

To grasp the workings of the EU in recent years, one must examine the ascendancy of a governing mode centred on the logic of emergency. This is the book's organising thesis. The idea of extreme circumstances that need to be overcome, and that give licence for unconventional measures of last resort, has become central to how decisions are made. It has shaped the practice and legitimisation of governing, the means by which authorities coordinate their actions and seek compliance. The book's aim is to unfold this logic, examining how its practices and ideas hold together. As I aim to show, with the concept of emergency rule one grasps not just how a certain socio-economic order comes to be entrenched, but how the particular way this is done disarms the democratic forces that might resist it.

Emergency rule is an old idea. In one form or another, it has been enacted and theorised from the ancient Roman Republic to the modern state. But it has now become fully cross-border in range, in the process acquiring a new set of dynamics. It is a distinctively transnational politics of emergency one sees in Europe more recently. This is true of the threats it is framed as a response to. Quasi-natural forces of the socio-economic sphere are cast in transnational terms, just like the things they are said to endanger. Indeed, officials highlight their cross-border character to underline the necessity of coming to terms with them. Unconfined in space, they threaten to be unconfined in their consequences. Their wide geographical extension becomes part of the rationale for governing from afar. The securitisation of socio-economic affairs goes hand in hand with their scaling up to the transnational level.

Equally distinctive is the mode of governing itself. Whereas emergency rule has tended to be conceived as concentrating power in the hands of a unitary sovereign, here one sees the interplay of national governments with supranational agents of various kinds, working through the EU and around it. Decisions involve executive agents spread across multiple institutions and territories, without a clear hierarchical relation. Schmittian themes of sovereign exceptionalism have had a recent renaissance, but the target of our enquiry involves a significant reworking. This is an emergency politics informally co-produced by the many.

When scholars reach for the analytical frame of emergency and exception, some characteristic motivations tend to be in play. Three typical concerns come to mind, not all shared by this book. The first is a preoccupation with the rule of law, particularly how it can be maintained in extreme situations, and what is implied for the concept of the rule of law itself. 
Extraordinary moments become the test case for the limits of law. This book is not part of that genre, being political rather than legal in focus. Nor does it belong to a second body of work that sets its task as to define when emergency rule is legitimate. In the post-9/11 world, much scholarship has engaged in a normative project of defending the recourse to exceptionalism, from extraordinary rendition to torture. As will become clear, I have little such desire to rationalise the practice. Closer to the book's inspiration is a third tradition, in which the politics of emergency is approached as a practice of authoritarian rule, a window onto the ways in which democratic control is subverted or forestalled. Exploring emergency politics as a mechanism of power, Naomi Klein's work on the 'shock doctrine' belongs to this critical tradition, as does the work of such authors as Bill Scheuerman, Bonnie Honig and Andreas Kalyvas. Concerns of power and democracy are central to this book, with a focus on the challenges of executive usurpation. But I am interested also in what emergency rule can tell us about the EU's workings, and the light it can shed on European politics more widely. I approach the politics of emergency as problematic, in other words, but also as potentially instructive.

In the study of EU politics, the notion that challenging times can be the motor of change is commonplace. Indeed, that the EU has been built and strengthened through a series of crises is something of a disciplinary cliché. There is no need for a new book restating and glossing Jean Monnet's dictum 'that Europe would be built through crises, and that it would be the sum of their solutions'. ${ }^{2}$ Such ideas have been thoroughly absorbed. But while they highlight the centrality of crisis politics in the international setting, they are limited in important ways. Perhaps the least of these is a tendency in EU scholarship to pose the matter in mechanistic terms, as a question of how breakdowns in integration are overcome. Crisis is approached as a moment in which the limits of a system are exposed, generating functional pressures for adaptation and innovation. Institutional change tends then to be read as a process of coming to terms with necessity, whether rooted in evolving socio-economic circumstances or the inadequacies of institutional design. Such accounts resemble those of public authorities themselves, who use them to rationalise their actions.

What gets marginalised are the political implications of what is done in the name of crisis response, as well as the very significance of measures being rationalised as such. A crisis suggests the breakdown of a whole, whereas typically one is dealing with developments uneven in their effects, more critical from some material and ideological perspectives than others, and a true threat mainly for those deeply invested in the status quo. Actions always exceed mere functional adaptation, and that they are rationalised as crisis measures entails generalising the

\footnotetext{
${ }^{1}$ Jean Monnet, Memoirs, trans. Richard Mayne (London: Collins, 1978), p.417.
} 
perspective of some to be the perspective of all. One needs to recognise not just the intuitive point that crises can be instrumentalised to serve political ends, but that the very handling of situations as exceptional ones demanding actions of last resort is consequential in itself. By speaking of emergency politics, one brings these governing rationalities to the fore, and treats them as a self-standing phenomenon of investigation rather than the dependent effect of functional demands.

There is a second move to be made, important again for EU study. Amongst those avoiding a purely functional approach, there remains a tendency to see crisis politics as bound up in the specifics of particular policies and the shocks they are exposed to. The emphasis falls on what is particular to a given domain in a certain period. Interpretations of EU crisis politics that focus on the specifics of eurozone design are an example. Even as this can generate insightful analysis, it casts crisis politics as the symptom of a certain situation.

What is then overlooked is how the politics of emergency, as a wealth of wider scholarship confirms, constitutes a more general governing mode, independent of the specifics of a particular context. It is typically hard to localise in time: rather than the method of an isolated episode, it can be invoked recurrently, even indefinitely. Although the discourse may be about exceptional circumstances, temporary arrangements and extraordinary measures, one should avoid reproducing such assumptions in analysis: it is exactly ideas of the self-contained episode that may need to be questioned. Likewise, one should be attentive to the continuities across domains, as common factors encourage recourse to similar methods. As this book aims to show, in the practices of emergency rule one sees the crystallisation of long-term tendencies irreducible to any one policy field. One sees part of a broader shift towards more coercive forms of rule under conditions of weakening democratic authority.

More particularly, the transnational politics of emergency marks, I suggest, the extent to which executive power has allowed itself to be reabsorbed into the socio-economic sphere, reversing the modern-democratic project of constructing political authority as an autonomous order. It is the culmination of a process of permeation and subordination, one that finds its highest form in the institutional arrangements of the transnational sphere - in the network of national, intergovernmental, supranational and cross-cutting decision-making structures. Although European integration has often been advocated as a process of taming socio-economic forces, it has produced new sites of exposure and adaptation. In place of the aspiration to set priorities and weigh normative claims, executive power has come to embrace a reactive approach centred on adjusting to the force of presumed necessity. The authority of political and legal norms becomes conditional on their compatibility with socio-economic demands. 
Whereas the emergence of the modern democratic state was widely conceived and rationalised as the de-personalisation of power and its regularisation, decision-making today is increasingly relocated to ad hoc settings that escape codification and depend on individual discretion. The informalisation of power is widespread. The transnational politics of emergency is the context in which these tendencies find their most concentrated expression, as well as a key context for efforts to rationalize and legitimize them.

The major theories of EU politics, still variations on intergovernmentalism and functionalism, are generally institutionalist accounts. In one way or another, they focus on the roles, rules and interests of institutional agents, taken as differentiated and relatively enduring. What they underplay are the informal, cross-institutional ties that emergency rule brings forward. Most at ease when examining the agendas pursued by states or supranational institutions, they are less equipped to discuss what cuts across these formations - the ideological and socioeconomic influences common to a wide array of executive agents, or the shared claims to authority they make. Emergency rule sees institutional structures bypassed or reshaped in the image of these networks and demands. Beyond mere redistributions of power across distinct and stable entities - the Commission, Council, states and so on - one sees shape-shifting structures and makeshift arrangements like the Troika that are ambiguous in status and uncertain in duration. Power is personalised, and detached from the bureaucratic routines that support talk of institutional agendas and interests.

Disputes over sovereignty are one of the leitmotifs of emergency politics. When existing norms are broken, the inevitable question will be whether those doing so were entitled to. Did they have the authority to identify the circumstances as exceptional and to prescribe an extraordinary response? In recent European politics one sees renewed efforts to answer with certainty the sovereignty question that has tended to be avoided in the EU. Emergency politics returns it to the table. But while the question may be posed with renewed force, it is a misleading one in current conditions if one seeks answers in the form of a pre-eminent institution. Executive power has become blurred with that of agents of the socio-economic domain to the extent that political exceptionalism is a joint endeavour.

When first writing on this topic in the early $2010 \mathrm{~s},{ }^{2}$ I focused on measures taken in an especially intense phase of eurozone crisis politics - between the first Greek bailout and the making of the Fiscal Compact. While this remains an exemplary case of emergency politics in the $\mathrm{EU}$, one to which this book continues to refer, the passing of time makes a broader view possible. The intention is to step back to consider the longer-term factors shaping these practices,

\footnotetext{
${ }^{2}$ Jonathan White, ‘Emergency Europe’, Political Studies 63 (2) (2015), pp.300-18.
} 
as well as some of the legacies arising. Emergency rule marks the radicalisation of existing tendencies, but it also leaves its own distinct traces. It points not just to a set of institutional transformations but to a potentially enduring recalibration of authority. Despite the emphasis on exceptionality, emergency rule sets precedents for what follows. Notable is not just how extreme conditions come to be invoked at a particular moment but how they become a reference-point for future actions. When the Italian President made his provocative intervention in May 2018 in the ministerial appointment process for the newly-formed Lega / Movimento 5 Stelle (M5S) government, it was with explicit reference to the threat of renewed uncertainty on the financial markets: the language of 'the spread' that had dominated Italian public discourse in the autumn of 2011 was pointedly emphasised once more. ${ }^{3}$ A period of emergency, however purportedly unique and self-contained, generates echoes that are heard down the years. The danger of a relapse into yesterday's crisis, and the need to ward off tomorrow's, become persistent themes in the discourse of power. The effect is that ideals of authority grounded in democracy, technocracy and proceduralism are challenged not just within the bounds of a delimited episode but in more open-ended and lasting ways.

There is another way that emergency politics leaves its mark: in shaping the political response it meets. Part of the commonsense of recent political commentary has been that a rebellion is unfolding against the policies and authorities of the liberal order, typically framed with the category of populism. As this book argues, such diagnoses typically miss something crucial, overlooking how a central strand in these counter-movements is exactly the repudiation of emergency rule, i.e. of extraordinary decisions rationalized by appeal to necessity. As we shall examine, what goes by the name of populism tends to be not just the critique of a failure of policy, nor the condemnation of detached and corrupt elites, but of the genuflection of authorities before ramped-up socio-economic demands. It is a critique of political acquiescence.

While emergency rule entails frenetic decision-making, its decisions are rationalised as unchosen and unavoidable both in substance and timing. To anticipate a distinction we shall come to, it is characterised by heightened executive activity - or 'doing', as I term it - coupled with heightened disavowals of agency, i.e. the capacity to choose freely between options. Emergency rule responds to forces it casts as all-powerful. What tends to be called populism is in significant part a repudiation of the discourse and performance of necessity that emergency politics puts centre-stage. Here one sees how the concept of emergency is valuable not just for understanding executive power in the EU, but also for grasping its critique.

\footnotetext{
${ }^{3}$ For Mattarella's own account of his actions: http://www.quirinale.it/elementi/1417; on the new concept of 'lo spread' in Italian public discourse: https://www.ilpost.it/2015/03/07/storia-spread/; also Ch. 3.
} 
Although in many ways a very British affair, in the currents of Brexit one saw such themes converge. With its denunciations of 'Project Fear', the 2016 Leave campaign was, amongst other things, a rejection of the politics of necessity and a call for renewed agency. It defined itself by its hostility to the ideas of economic emergency put forward by forecasters in the Treasury, IMF, EU institutions and the markets. It was, by its own account, an effort to reassert the primacy of politics over economics, identifying this as a project for the sovereign nation-state acting in contradistinction to the dynamics of the transnational sphere.

Yet at various points over the following years, it seemed the best hope of delivering Brexit in any form would involve relying on the same themes of compulsion and urgency the Leave campaign had condemned. From the winter of 2018/19, the prospect of market turmoil should the Withdrawal Agreement be voted down was raised by central bankers and political strategists to focus minds in Parliament. ${ }^{4}$ The EU's many veto players were long highlighted by the UK government to emphasize the difficulties of renegotiation, and reiterated by EU representatives equally keen to see a deal concluded. Postponing votes and debates in Parliament, the Prime Minister's circle repeatedly sought more time to highlight the stakes of 'no deal'. MPs were cast as obstacles from all sides, and the likelihood of chaos and emergency rule was openly invoked by representatives of the UK and the EU alike. ${ }^{5}$

In the manner of a self-cancelling prophecy, the prospect of disorder was raised as a way to pursue order, to encourage all but the most reckless to fall in line. In the manner of a selffulfilling prophecy, the same strategy provoked further anxiety within markets, business groups, trade unions, and EU authorities, giving new fodder for the politics of emergency. ${ }^{6}$ For all its specificities and unintended outcomes in this context, the pattern of genuine threats amplified by the tactics of a government was a local reprise of manoeuvres seen repeatedly in Europe's crisis politics of the 2010s. Leading figures in the executive sought to sustain and even bolster themselves in adversity by drawing on the logic of exception.

A larger theme we shall explore is how rejoinders to emergency politics may reproduce some of its defining characteristics. Efforts to challenge its political legacy may include elements of exceptionalism themselves - both when agents seek to exit the EU and when seeking to contest

\footnotetext{
${ }^{4}$ https://www.ft.com/content/702e5dbc-ed8d-11e8-89c8-d36339d835c0

5 See e.g. Caroline Wheeler, 'UK ready to declare martial law to avert no-deal chaos', Sunday Times, 27 January 2019: https://www.thetimes.co.uk/edition/news/uk-ready-to-declare-martial-law-to-avert-no-deal-brexit-chaosbfqgzzlrw; also PM May's notorious speech of 20 March 2019 (https://www.theguardian.com/politics/ 2019/mar/20/acting-like-trump-theresa-may-sparks-mps-brexit-fury) and the wilder acrobatics of the Johnson government. On the EU side, see the Commission's proposals of 19 December 2018: https://ec.europa.eu/info/sites/info/files/com-2018-890-final.pdf

${ }^{6}$ See e.g. the joint letter of the UK Confederation of British Industry (CBI) and Trades Union Congress (TUC) to PM May of 21 March 2019, warning of a 'national emergency' should the Government keep to its course: https: //www.theguardian.com/politics/2019/mar/21/heads-of-tuc-and-cbi-write-to-may-pleading-for-a-brexitplan-b
} 
it from within. One sees a counter-politics of emergency, emerging 'from below' in parties and movements, replete with its own set of normative challenges. This is where executive discretion meets the practices of disobedience. How a defensible rejoinder to the transnational politics of emergency might look is one of the guiding questions for the book's later chapters.

Much of the recent scholarship on emergency rule displays a liberal concern for its effects on individual rights, notably those of assembly and arrest. Such focus is in keeping with a concern for the rule of law. Yet the implications of emergency rule for democracy are no less pronounced, especially when the phenomenon is transnational in scope and the range of decisionmakers extends well beyond those elected by the population affected. Emergency rule relies on and entrenches asymmetries between executives on the one hand, be they in governments, supranational institutions or functional agencies, and those who would scrutinise them on the other. It is the political implications of emergency rule that are my focus.

There are those for whom executive pre-eminence and decision are part of a positive story to be told of crisis management. The rise of the 'executive unbound' is admired by some as the rise of an agent that can get things done, more capably than legislatures and lower-tier bureaucracies. ${ }^{7}$ The argument has been powerfully advanced in the US, and shows signs of being adopted in Europe too. Taking stock of the EU's recent transformations, and the role of the European Council especially, Luuk van Middelaar endorses the 'emancipation of the executive' he sees in progress, as a way to build strength and global standing. ${ }^{8}$ Such transformations mark the polity's coming of age, its increasing self-awareness and governing capacity. Political authority consolidates in the encounter with pressing 'events', albeit some eggs may be broken along the way. As will become clear, I am sceptical. Even when elected officials are to the fore, the democratic costs tend to be high, and not just in the short and medium term. More than just improvisations, the EU has been witness to suspensions and evasions, and these leave a lasting legacy. Moreover, the executive forms emerging remain closely tied to defined policy goals, however emancipated from law and procedure they may be. They are committed to the reinforcement of existing socio-economic structures, and thus in an important sense mark continuity rather than new beginnings.

The following is a concept-driven book. Its main contribution is intended to lie in the concepts its advances and the connections suggested. Rather than to present an historical account of the recent past, its aim is to explore the logics in play and the terms best suited to grasping them. Emergency stands as the master concept, but the following chapters put forward a range

\footnotetext{
${ }^{7}$ Eric Posner and Adrian Vermeule, The Executive Unbound: After the Madisonian Republic (Oxford: OUP, 2011).

${ }^{8}$ Luuk van Middelaar, Alarums and Excursions: Improvising politics on the European stage (Newcastle: Agenda, 2019), pp.175-6.
} 
of others, analytical and normative, intended to clarify contemporary practice and its organising ideas. Amongst those we shall become familiar with are de-institutionalisation, crisis expertise and constitutional reassurance. A number of heuristic dichotomies are proposed, including those of know-that and know-how, of agency and doing. In addition, some of the concepts of contemporary discourse that are most familiar - democracy, technocracy, sovereignty, authority and populism - will be placed in a distinctive light.

Conceptual work of this kind relies on moving back and forth between theoretical reasoning and empirical evidence, using the latter to refine the former. If the outcome is better insight into the context at hand then the exercise fulfils its primary goal. But the hope is that the categories of analysis developed are transferable to other contexts and can be used to draw connections across them. Even as the EU's emergency politics of the 2010s recedes from the immediate present, some of the insights it can yield should retain their broader significance. The EU in this period stands as an exemplary case of a kind of emergency rule too rarely examined: socio-economic rather than geo-military in focus, transnational and dispersed rather than statist in range, and the means by which not just individual rights but norms of collective selfdetermination are cancelled or forestalled.

In the book's first chapter, I outline some key features of the politics of emergency, its distinguishing elements in the transnational context, and the value of this analytical frame. The account is built on an analysis of the EU's handling of economic malaise in the 2010s. Central to the political imaginary in these years was the figure of the Troika. Though on one level just a term of public condemnation, on another it encapsulated some deeper truths about the politics of the time. Specifically, the Troika concept expressed a politics based on ostensibly impermanent, unconventional arrangements for defined purposes, governed by an agenda of speed and urgency, and propelled by trans-institutional executive power. Taken together, these features amount to a governing mode that theories of emergency rule can illuminate. They help us to understand how such features interrelate, and draw attention to aspects under-emphasised in current scholarship, including the shape-shifting of institutions and the networks that cut across them. Equally, classical takes on the sovereign state of exception can be a foil by which to identify the distinctive aspects of EU exceptionalism, including its informal character and its co-production by many actors. The chapter acts as a point of departure for thinking about the specificities of transnational emergency rule.

As Chapter 2 argues, certain structural features of the EU create an in-built vulnerability to discretion under the sign of emergency. Some of the basic drivers are long-standing, even if their full implications become visible only in the context of more recent changes. An important feature is how the EU order has been constructed to serve particular purposes. Since its origins 
in the 1950s, European integration has entailed the creation of institutions whose rationale is to advance and maintain certain policy ends - notably those underpinning the 'four freedoms' of the common market, understood as ways to advance broader goals of peace and prosperity. As the chapter argues, the effect is that policy commitments have been privileged over procedural arrangements. Rather than self-standing entities that can be put to different ends, broadly on the model of the modern state, one sees institutions evolving with the policies, and liable to be sidestepped should they fail to serve them. There is an instrumentalist orientation to the transnational polity that makes its arrangements precarious when the going gets tough. Moreover, a nonhierarchical constitutional structure does little to inhibit these restructurings, indeed arguably gives further encouragement. A long-standing idea in constitutional thought is that the diffusion of power across many institutions can create political paralysis, especially when the division of roles is weakly underpinned constitutionally. Arriving at common policies, enforcing and revising them is the work of many hands, always potentially convoluted. The ideas and practices of emergency are a way to galvanise action, coordination and innovation across a diverse and potentially recalcitrant institutional field.

Developments in recent decades have pushed the EU from a structural vulnerability to emergency rule to an increasing reliance on it. Susceptibilities once latent have become increasingly manifest. As Chapter 3 shows, this happens in the context of a series of challenges to political authority. By the turn of the millennium, leaders found themselves surrounded by powerful non-state actors claiming the authority to interpret socio-economic conditions, to make sense of moments of uncertainty, and to specify the responses they demand and when. Market analysts and ratings agencies are emblematic examples of these emergency interpreters of the private sphere. Structurally attentive to conditions of volatility and stress, such agents foster an atmosphere conducive to the politics of emergency, and - as those often invested in maintaining and reinforcing aspects of the status quo - concertedly influence the considerations elevated to the status of a threat. Moreover, due to changes within the field of executive power itself, the voice of these agents carries ever further into decision-making circles. The rise of governance marks the rise of an executive ethos characterized on the one hand by the decisive prioritizing of problem-solving capacity over politico-legal norms, and on the other by the search for public consent in mechanisms other than responsiveness to public will. The first reinforces a willingness to escape procedural constraints, while the second encourages the serial invocation of exceptional circumstances as a way to give citizens reason to accept unpalatable decisions they were left out of. The politics of emergency is a way of coping with weakening public authority in the age of governance. 
The events of the 'Euro crisis', from the handling of market pressures to the ECB's reincarnation as lender of last resort, are just one manifestation of this governing pattern. The chapter goes on to examine how these dynamics, rather than exclusive to one scenario or policy area, play out across a wider field of transnational decision-making. The handling of economic malaise is paired with the political response to migration in the years after 2015, with the suggestion that both are the consequence of executive deference to non-state power and a governance approach that seeks validation in fast action.

Emergency politics has become recurrent in the EU. Interestingly, though, it tends to be coupled with the suggestion that it will soon be consigned to the past. Notions of a "normalityto-come' are part of its legitimising apparatus, and a plausible aim if the rhetoric of emergency is not to be devalued by overuse. Yet such notions of imminent normality can be little more than an ideological claim unless the emergency regime can be credibly terminated. Once embarked on emergency rule, executive agents face questions of whether, how and when they will end it. Can they draw a line such that their unconventional measures are seen to be contained: can they provide constitutional reassurance?

Chapter 4 analyses the preconditions for an act of separation between the exception and its aftermath. Given the informal character of EU emergency rule, this is a political rather than legal question, centred on credible claims to the effect that crisis has been superseded, or that executive power is newly constrained, or that it is now peopled by those less inclined to exceptionalism. The chapter articulates and explores these possibilities. It questions whether the resources for demarcating emergency rule from its aftermath are available. Partly a matter of the amorphousness and uncertainty of the extreme circumstances cited, it is also a function of the EU's structure. Features of emergency rule will tend to endure, with important implications for the kind of authority that can be accommodated. Procedural authority is hard to renew, even for those who seek it, and its likely weakness one of the legacies of emergency rule. Through the prism of the EU's constitutional particularities, the chapter addresses an under-examined aspect of exceptionalism more generally - the constitutional problems arising from the difficulty of localising it in time.

When procedural authority is persistently in doubt, one can expect the invocation of other forms of authority. Given its long-standing association with EU politics, especially relevant is that of technocracy. On one view, emergency rule spells problems for expert-led rule, challenging existing knowledge and encouraging the intrusion of non-scientific criteria on decision-making. Especially when crisis management forces collaboration between multiple institutions, the technocratic credentials of each come under strain. Yet as Chapter 5 tries to show, emergency and technocracy are also complementary, and some may embrace 
exceptionalism precisely to promote technocratic authority. Knowing how to act in atypical situations is in some ways the very measure of expertise. Only in irregular times can the claim to expert status be renewed. Examining recent EU experience, the chapter shows how claims to expertise can span theoretical and practical knowledge. Emergency rule disrupts claims to scientific 'know-that', and encourages would-be technocrats to rely on a form of crisis expertise centred on practical know-how. Ideals of techne give way to phronesis. Rather than the termination of technocratic logic, emergency rule signifies its redefinition - and in politically problematic ways. This recalibration facilitates the diffusion of 'technocrats' across different institutions, including those meant to be democratic, and leads to a precarious form of authority resting on weakly-underpinned trust. The analysis contributes both to our understanding of the EU and how to think about technocracy more generally.

Questions of authority raise questions of public consent. Here the book moves to examine rejoinders to emergency rule: the critical responses it generates and, more normatively, those one might wish to see. I proceed from the observation that the politics of emergency, with its suggestion of decisions born of necessity rather than choice, consolidates an image of the EU as the negation of political agency. Chapter 6 examines how such actions invite their opposite: a politics defined by its rejection of necessity and the celebration of political volition. Here one sees another of the longer-term legacies of emergency rule, and in particular how it brings sovereignty themes to the fore (think Brexit). The mobilisations across Europe commonly studied under the heading of 'populism' gather, I suggest, much of their wider appeal from the promise to restore political agency - a promise independent of the other features typically ascribed to them, and which the term populism can serve to obscure. With the distinction between the politics of necessity and volition, one can better understand the motivations in play, and avoid casually attributing the success of such movements to their least desirable features (nativism, anti-politics and the like). Further, one gains insight into the reasons why established executive powers may be moved to respond harshly - so as to protect the securitisation moves on which emergency rule depends. The chapter's final section examines how the spectre of such counter-mobilisations may be invoked by established powers as reason for further constraining measures. This raises the unwelcome prospect of escalation - but also a persistent demand for agency that could be harnessed for democratic ends.

Efforts to stabilise the political scene and to ward off the next crisis typically involve moves to restrict the discretion of all but the most powerful. Attempts to lock in the policy regimes of the new order are a characteristic feature of emergency rule. Besides reinforcing the appeal of a voluntarist stance, one implication is that those wishing to reshape that order may be compelled to do so by rule-breaking means. But if one rightly has concerns about the unbound 
character of emergency rule, what is one to make of the kinds of transgression that may be required to overturn its legacy? Chapter 7 examines these practices of resistance using the concept of disobedience. From the Syriza-led government in Greece to the Movimento 5 Stelle / Lega government in Italy, one has seen the appearance of parties and movements stating a willingness to challenge the rules of the post-emergency EU. The contours of an extraordinary politics 'from below' start to emerge, as dissenters seek to reform or unmake the status quo.

The concept of disobedience offers both an interpretative frame for these mobilisations and the basis for their evaluation. One of the chapter's purposes is to develop criteria by which to distinguish principled from illegitimate forms of extra-legality, and to connect them to developments on the ground. As a contribution to the political theory of civil disobedience, it reflects on the kinds of agent that can lead it, showing how one of the distinctive features of the transnational realm is to enable a form of disobedience led by parties. In addition to the activities of national parties, some of the possibilities are foreshadowed in pan-European groups such as the democracy movement DiEM25. With the concept of principled disobedience, one has the basis on which to understand what motivates such responses to emergency rule, as well as to take critical stock. The chapter concludes with some reflections on the normativity of exceptionalism more generally.

Is there the prospect of an escape from the politics and counter-politics of emergency in today's Europe? Disobedience marks an incomplete break with the logic of exception, so how might a more thorough rejoinder look? This question is taken up in the penultimate chapter. In the nation-state setting, answers are typically sought in procedural checks on executive discretion, whether in the form of legal constraints upheld by courts, or strategies of institutional design that make emergency rule less appealing. There is much to be said for such moves in the EU, and proposals exist of how the EU might benefit from a constitutional reorganisation of this kind. But as the chapter argues, what tends to be missing is an account of the political will that could support such initiatives. This matters because procedural remedies are likely to depend on the approval of those most likely to block them - the established agents of executive power. Moreover, even once instituted, such changes need to be maintained, given the range of socioeconomic and political forces ranged against them.

The chapter develops an account of the political restraint of emergency rule based on mobilisation within broadly existing structures. Only, I suggest, the re-embedding of decisionmaking power in a world of ideas-based collectives can realistically temper the tendencies at hand. With emergency politics symptomatic of the hollowing of parties, challenging it entails strengthening the ties of partisanship, both as these may constrain directly the discretion of representatives holding authority, and as they may influence it from a position of opposition. The 
chapter draws and develops on debates about transnational partisanship, connecting them to a discussion of the structural preconditions of opposition. Emphasised is the significance of temporal features: the experience of modern democracy suggests that the periodicity of institutions has been an important underpinning for critical opinion. Associations come alive by virtue of their rhythms, and ideologically strong and enduring modes of opposition depend on recurring moments of visibility and conflict. By contesting elections at all political levels, but most especially by contesting national elections as transnational partisans, those critical of executive discretion under the sign of emergency may take steps towards its political constraint.

But there is a deeper significance too to the rhythms of partisanship, to do with the demarcation of political from socio-economic power. With its urgency of word and deed, emergency rule signifies the subordination of political decision-making to the temporality of the socio-economic sphere. One of the contributions of institutions of periodicity in the state context has been to mark out the autonomy of political time. By establishing time-structures independent of the passage of events, such institutions offer a framework for the coordination of opinion at the level of general principle, abstracted from the specificities of a given context. If the EU is to be more than the sum of ad hoc responses to socio-economic forces, this kind of demarcation seems crucial. Here lie some of the resources by which to rebuild the autonomy of executive power and make it susceptible to democratic control.

The concluding chapter offers a restatement of why the politics of emergency is something one should wish to see contained. It highlights a feature that reinforces one of the problems of the EU's political culture: the tendency to frame events as a series of one-off, sui generis episodes, each detached from a larger historical and normative frame. With their emphasis on exceptional measures for exceptional times, the protagonists of emergency rule assert the extraordinary nature of the situation they face. Emphasising that their actions are of last resort, they claim to be bound by no precedent and to set no precedent. Theirs is a politics of discretion grounded in the supposed particularity of the moment: a politics of the singular. As the chapter argues, the relation between democracy and the unique is double-edged. On the one hand, these are the conditions of innovation, experiment and creativity in politics. Discretion in unfamiliar circumstances is what enables a polity to evolve, a thought expressed in the narratives of integration-through-crisis that have tracked the EU's history. But there is a darker side to the politics of singularities. Without the recognition of continuities and the insistence on standards and principles that bridge events in their specificity, governing agents are cut too much slack. The critical scrutiny of power and the identification with its demands depend on the recognition of what is not particular to the moment - on moving beyond the politics of singularities. 
As the book aims to show, the transnational politics of emergency powerfully shapes how institutions and policies have come to be made, inside the EU and alongside it. A world of institutional discontinuity and executive discretion co-exists with, and helps support, a socioeconomic order relatively enduring until now in its essentials. Although the logic of emergency evokes exceptional departures from a stable framework, it should be studied not just as the governing rationality of particular episodes but as something that selectively locks in the past and shapes anticipation of the future. Although it has become customary to treat the EU as afflicted by a succession of unique challenges, ranging across money, migration, geopolitics and more, one should look for the continuities that span the domains.

Perspectives on the EU are often binary in form - for or against, leave or remain - and one effect of the Brexit process has been to accentuate this. In Britain and beyond, critical analysis of the EU has become associated with calls for exit, dissolution, or predictions of demise. At the same time, one of the more unfortunate legacies of the Brexit story may turn out to be strengthening the opposing sentiment: an undiscriminating attachment to the European project across sizeable sections of the EU public. Sympathetic critique is side-lined in both cases. This book avoids dismissing the EU, either as destined to fail or as something whose problems can be left to others. But it also aims to highlight some deep-seated flaws, to explore how EU structures can magnify certain problems and entwine them with dynamics that are distinctive to the transnational sphere.

While, for many, European integration has been a process of constraining sovereignty and the wayward exercise of executive power, the effect it seems has been to create the conditions for a new kind of political exceptionalism, different in structure but no less problematic. It is being contested in today's Europe in ways that may limit it, but the prospect of its resurgence will not go away. Deeper than any one set of institutional forms, there is little reason to suppose even the disintegration of the EU would bring the politics of emergency to an end. Indeed, were the EU to dissolve or splinter, the arising conditions would surely favour further appeals to executive discretion under the sign of emergency. Emergency Europe would persist. This is a mode of rule difficult to consign to the past, even as determined agents seek ways to contain it. It is worth getting familiar with its forms and rationalities. 


\section{Bibliography}

Ackerman, Bruce (2006), Before the Next Attack: Preserving Civil Liberties in an Age of Terrorism (New Haven: Yale UP).

--- (1991), We the People: Foundations (Cambridge, MA: Harvard UP).

Adey, Peter, Ben Anderson and Stephen Graham (2015), 'Introduction. Governing Emergencies: Beyond Exceptionality', Theory, Culture \& Society 32 (2) 3-17.

Agamben, Giorgio (2005), State of Exception (Chicago: Chicago UP).

--- (2013), 'The Endless Crisis as an Instrument of Power', 4th June https://www.versobooks.com/blogs/1318-theendless-crisis-as-an-instrument-of-power-in-conversation-with-giorgio-agamben

Akin, William (1977), Technocracy and the American Dream: The Technocrat Movement, 1900-1941 (Berkeley: U. of California Press).

Altman, David (2011), Direct Democracy Worldwide (Cambridge: CUP).

Anderson, Ben (2017), 'Emergency futures: exception, urgency, interval, hope', Sociological Review 65 (3).

--- (2010), 'Preemption, Precaution, Preparedness: Anticipatory Action and Future Geographies', Progress in Human Geography 34(6): 777-98

Anderson, Christopher J., André Blais, Shaun Bowler, Todd Donovan, and Ola Listhaug (2005), Losers' Consent: Elections and Democratic Legitimacy (Oxford: OUP).

Anzia, Sarah F. (2013), Timing and Turnout: How off-cycle elections favor organized groups (Chicago: U. of Chicago).

Aradau, Claudia (2004), 'Security and the Democratic Scene: Desecuritization and emancipation', Journal of International Relations and Development 7, pp.388-413.

Arendt, Hannah (1990), On Revolution (London: Penguin).

--- (1961) Between Past and Future (London: Penguin).

Asmussen, Jörg (2012), 'Stability guardians and crisis managers: central banking in times of crisis and beyond', Lecture at the Goethe-Universität Frankfurt, 11 Sept. (https://www.ecb.europa.eu/press/key/date/2012/html/sp120911.en.html).

Auer, Štefan (2019), 'Merkel's Germany and the European Union: Between Emergency and the Rule of Rules', Government and Opposition pp.1-19.

Balzacq, Thierry, Sarah Léonard and Jan Ruzicka (2016), “'Securitization” revisited: Theory and cases', International Relations 30 (4), pp.494-531.

Baquerro-Cruz, Julio (2012), 'Legal Pluralism and Institutional disobedience in the European Union', in Matej Avbelj \& Jan Komárek (eds.) Constitutional Pluralism in the European Union and Beyond (Oxford: Hart).

Barroso, José Manuel (2014), Valedictory speech by Commission President to the European Parliament, 21 October, Strasbourg.

--- (2011), Statement to the press following the meeting of eurozone Heads of State or Government, Brussels, 27 October, speech/11/713.

Bauer, Michael and Stefan Becker (2014), 'The Unexpected Winner of the Crisis: the European Commission's Strengthened Role in Economic Governance', Journal of European Integration 36 (3), pp.213-229.

Bauman, Zymunt (2004), 'From Social State to Security State', in Bauman, Europe: An Unfinished Adventure (Cambridge: Polity).

Beck, Ulrich (2013), German Europe (Cambridge: Polity).

--- (2009), 'Critical Theory of World Risk Society' Constellations, 16 (1).

Becker, Stefan, Michael W. Bauer, Sara Connolly and Hussein Kassim (2016), 'The Commission: Boxed in and constrained, but still an engine of integration, West European Politics 39 (5), pp.1011-31.

Beckert, Jens (2016), Imagined Futures: Fictional expectations and capitalist dynamics (Cambridge MA: Harvard UP).

Bellamy, Richard (2001), 'The Rule of Law and the Rule of Persons', Critical Review of International Social and Political Philosophy 4 (4), pp. 221-251.

Benz, Arthur (2003), 'Compounded representation in EU multi-level governance', in Beate Kohler-Koch, (ed.), Linking EU and National Governance (Oxford: OUP), pp.82-110.

Best, Jacqueline (forthcoming), 'Technocratic Exceptionalism: Monetary Policy and the Fear of Democracy', International Political Sociology.

Beukers, Thomas, Bruno de Witte and Claire Kilpatrick (eds.) (2017), Constitutional Change through Euro-Crisis Law (Cambridge: CUP).

Bevan, Gwyn and Christopher Hood (2006), 'What's measured is what matters: Targets and gaming in the English public health care system', Public Administration 84 (3), pp.517-538.

Bhambra, Gurminder K. (2017), 'The current crisis of Europe: Refugees, colonialism, and the limits of cosmopolitanism', European Law Journal 23 (5), pp. 395-405.

Bickerton, Chris J. (2012), European Integration: From Nation-States to Member-States (Oxford: OUP). 
--- and Carlo Invernizzi Accetti (2017), ‘Populism and Technocracy: Opposites or Complements?', Critical Review of Social and Political Philosophy 20 (2), pp.186-206.

--- and Dermot Hodson and Uwe Puetter (2015), 'The New Intergovernmentalism: European Integration in the Post-Maastricht Era', Journal of Common Market Studies 53 (4), 703-722.

Biebricher, Thomas (2017), 'Ordoliberalism as a Variety of Neoliberalism', in Josef Hien and Christian Joerges (eds.) Ordo-Liberalism, Law and the Rule of Economics (Oxford: Hart).

--- (2013), 'Europe and the Political Philosophy of Neoliberalism', Contemporary Political Theory 12, pp.338375.

Bigo, Didier (2002), 'Security and immigration: Toward a critique of the governmentality of unease', Alternative 27 (Special Issue), pp.63-92.

Blyth, Mark (2013), Austerity: The History of a Dangerous Idea (Oxford: OUP).

--- and Richard Katz (2005), 'From Catch-all Politics to Cartelisation: The Political Economy of the Cartel Party', West European Politics 28 (1), pp.33-60.

Böckenförde, Ernst-Wolfgang (2010), 'Kennt die europäische Not kein Gebot?', Neue Zürcher Zeitung, $21^{\text {st }}$ June (https://www.nzz.ch/kennt_die_europaeische not kein_gebot-1.6182412).

von Bogdandy, Armin (2018), 'Ways to Frame the European Rule of Law: Rechtsgemeinschaft, Trust, Revolution, and Kantian Peace', European Constitutional Law Review 14, pp.675-99.

--- and M. Ioannidis, 'Systemic Deficiency in the Rule of Law: what it is, what has been done, what can be done' (2014) 51 Common Market Law Review, 59-96.

Böhm, Franz (1966), 'Privatrechtsgesellschaft und Marktwirtschaft', ORDO Jahrbuch für die Ordnung von Wirtschaft und Gesellschaft 17, pp.75-152.

Boin, Arjen, Paul 't Hart and Allan McConnell (2009), 'Crisis exploitation: political and policy impacts of framing contests', Journal of European Public Policy 16 (1).

Boltanski, Luk (2011), On Critique (Cambridge: Polity).

Bonefeld, Werner (2017), The Strong State and the Free Economy (Lanham: Rowman \& Littlefield).

Braunthal, J. (1960), History of the International, vol. I, 1864-1914 (New York: Praeger).

Brennan, Geoffrey, Lina Eriksson, Robert E. Goodin and Nicholas Southwood (2013), Explaining Norms (Oxford: OUP).

Brown, Wendy (2015), Undoing the Demos: Neoliberalism's Stealth Revolution (MIT: Zone Books).

Brubaker, Rogers (2017), 'Why populism?', Theory and Society.

Bruff, Ian (2014), 'The Rise of Authoritarian Neoliberalism', Rethinking Marxism: A Journal of Economics, Culture and Society 26 (1).

Brunkhorst, Hauke (2016), 'The European Dual State: the double structural transformation of the public sphere and the need for repoliticization', in Jiř́ Přibán̆ (ed.) Self-Constitution of European Society: Beyond EU politics, law and governance (London: Routledge).

--- (2014), Das doppelte Gesicht Europas. Zwischen Kapitalismus und Demokratie (Frankfurt/Main: Suhrkamp).

Bulmer, Simon, and Wolfgang Wessels (1987), The European Council. Decision-making in European Politics (London: MacMillan).

Buzan, Barry, Ole Wæver and Jaap de Wilde (1998), Security: A New Framework for Analysis, (Boulder CO: Lynne Rienner).

Buzan, Barry and Ole Waever (2009), 'Macrosecuritization and security constellations: reconsidering scale in securitization theory', Review of International Studies, 35 (2), pp.253-276.

Calhoun, Craig (2004), 'A World of Emergencies: Fear, Intervention and the Limits of Cosmopolitan Order', Canadian Review of Sociology 41 (4), pp.373-95.

Campesi, Giuseppe (2018), 'Crisis, Migration and the Consolidation of the EU Border Control Regime', International Journal of Migration and Border Studies 4 (3), pp.196-221.

Canovan, Margaret (2005), The People (Cambridge: Polity).

Caramani, Daniele (2017), 'Will vs Reason: The Populist and Technocratic Forms of Political Representation and Their Critique to Party Government', American Political Science Review 111 (1), pp.54-67.

Castelli Gattinara, Pietro (2017), 'The "refugee crisis" in Italy as a crisis of legitimacy', Contemporary Italian Politics 9 (3).

Celikates, Robin (2016a), 'Rethinking Civil Disobedience as a Practice of Contestation-Beyond the Liberal Paradigm', Constellations 23 (1).

--- (2016b), 'Democratizing civil disobedience', Philosophy and Social Criticism 42 (10), pp.982-94.

Centeno, Miguel Angel (1993), 'The New Leviathan: The Dynamics and Limits of Technocracy', Theory and Society 22 (3), pp.307-335.

Chalmers, Damian (2016), 'Crisis reconfiguration of the European constitutional state', in Chalmers, Markus Jachtenfuchs and Christian Joerges (eds.), The End of the Eurocrats' Dream: Adjusting to European Diversity (Cambridge: CUP).

Chalmers, Damian, Gareth Davies and Giorgio Monti (2014), European Union Law: Text and Materials (Cambridge: CUP). 
Chalmers, Damian and Barroso, Luis (2014), 'What Van Gend en Loos stands for', International Journal of Constitutional Law, 12 (1). pp.105-134.

Cheneval, Francis and Mónica Ferrín (2018), 'Referendums in the European Union: Defective by Birth?', Journal of Common Market Studies 56 (5), pp.1178-1194.

Clift, Ben (2018), The IMF and the Politics of Austerity in the Wake of the Global Financial Crisis (Oxford: OUP).

Codogno, Lorenzo, Guillaume Odinet and Flavio Padrini (2009), 'The Use of Targets in the Lisbon Strategy', Rivista di Politica Economica Jan-March.

Cohen, Elizabeth (2018), The Political Value of Time (Cambridge: CUP).

Cohen, Morris R. (1914), 'Rule vs Discretion', Journal of Philosophy, Psychology and Scientific Methods 11, pp.208-215.

Collins, Harry and Robert Evans (2007), Rethinking Expertise (Chicago: UCP).

Côté, Adam (2016), 'Agents without agency: Assessing the role of the audience in securitisation theory', Security Dialogue 47 (6), pp.541-558.

Curley, Tyler M. (2015), 'Models of Emergency Statebuilding in the United States', Perspectives on Politics 13 (3).

Curtin, Deidre (2014), 'Challenging Executive Dominance in European Democracy', Modern Law Review 77 (1).

--- (2009), Executive Power of the European Union. Law, Practices and the Living Constitution (Oxford: OUP).

Davies, William (2014), The Limits of Neoliberalism: Authority, Sovereignty and the Logic of Competition (London: Sage).

Davis Cross, Mai'a 2017), The Politics of Crisis in Europe (Cambridge: CUP).

--- and Xinru Ma (2015), 'EU crises and integrational panic: the role of the media', Journal of European Public Policy 22 (8).

Davitti, Daria (2019), 'Biopolitical Borders and the State of Exception in the European Migration "Crisis", European Journal of International Law 29 (4).

Dawson, Mark (2015), 'The Legal and Political Accountability Structure of 'Post-Crisis' EU Economic Governance', Journal of Common Market Studies 53 (5), pp. 976-993

Devlin, John F. (1991), 'The Baath Party: Rise and Metamorphosis', The American Historical Review 96 (5), pp.1396-1407.

De Wilde, Marc (2012), 'The Dictator's Trust: Regulating and Constraining Emergency Powers in the Roman Republic', History of Political Thought 33 (4), pp.555-577.

De Wilde, Pieter and Michael Zürn (2012), 'Can the Politicization of European Integration be Reversed?', Journal of Common Market Studies 50 (S1).

Dewey, John (1958), 'The Natural History of Form', in Dewey, Art as Experience (New York: Capricorn), pp.134-62.

Diab, R. (2015) The Harbinger Theory: How the Post-9/11 Emergency Became Permanent and the Case for Reform (Oxford: OUP).

DiEM25's July 2017 'guide to constructive disobedience': https://www.opendemocracy.net/can-europe-makeit/diem25/guide-to-constructive-disobedience

Dinan, Desmond (2016), 'Governance and Institutions: A More Political Commission' Journal of Common Market Studies 54, Annual Review, pp.101-116.

--- (2014), 'Governance and Institutions: The Unrelenting Rise of the European Parliament', Journal of Common Market Studies 52, Annual Review, pp.109-124.

Duchêne, Francois (1994), Jean Monnet: The First Statesman of Interdependence (New York: W. W. Norton \& Company).

Dyson, Kenneth (2013), 'Sworn to Grim Necessity? Imperfections of European Economic Governance, Normative Political Theory, and Supreme Emergency', Journal of European Integration 35 (3), pp.207-22.

Dyzenhaus, David (2006), The Constitution of Law: Legality in a Time of Emergency (Cambridge: CUP).

Eger, Thomas, Stefan Oeter and Stefan Voigt (2017), International Law and the Rule of Law under Extreme Conditions: An Economic Perspective. Contributions to the XIVth Travemünde Symposium on the Economic Analysis of Law (March 27-29, 2014) (XX: Mohr Siebeck).

Eichengreen, Barry (2015), Hall of Mirrors: The Great Depression, The Great Recession, and the Uses-and Misuses-of History (Oxford: OUP).

Ekengren, Magnus (2002), The Time of European Governance (Manchester: MUP).

Ellman, Michael (2010), 'Regional Influences on the Formulation and Implementation of NKVD Order 00447', Europe-Asia Studies 62 (6), pp.915-931.

Elster, Jon (2004), 'Comments on the paper by Ferejohn and Pasquino', I.CON 2 (2), pp.240-3.

Enroth, Henrik (2014), 'Governance: The art of governing after governmentality', European Journal of Social Theory 17 (1), pp.60-76.

D'Eramo, Marco (2013), 'Populism and the New Oligarchy', New Left Review 82 (July / August).

European Central Bank (2014a), 'Exchange of views of Benoît Cœuré with ECON on troika matters: Introductory remarks by Benoît Cœuré, Member of the Executive Board of the ECB', Brussels, 13 February (https:/www.ecb.europa.eu/press/key/date/2014/html/sp140213.en.html). 
European Central Bank (2014b), Replies to the questionnaire of the European Parliament supporting the own initiative report evaluating the structure, the role and operations of the 'troika' (Commission, ECB and the IMF) actions in euro area programme countries, 2014

(https://www.ecb.europa.eu/pub/.../140110_ecb_response troika questionnaireen.pdf)

European Commission (2016), 'Proposal for a Council Implementing Decision Setting out a Recommendation for Temporary Internal Border Control in Exceptional Circumstances Putting the Overall Functioning of the Schengen Area at Risk' (Brussels: EC).

--- (2015), 'Communication from the Commission to the European Parliament and the Council: A European Border and Coast Guard and effective management of Europe's external borders' (Brussels: EC).

--- (2015), 'A European Border and Coast Guard to protect Europe's External Borders', press release, $15^{\text {th }}$ December (Brussels: EC).

--- (2015), 'Completing Europe's Economic and Monetary Union' [Five Presidents' Report'], Report by JeanClaude Juncker, in close cooperation with Donald Tusk, Jeroen Dijsselbloem, Mario Draghi and Martin Schulz (Brussels: EC).

--- (2013), Response to the European Parliamentary 'Questionnaire supporting the own initiative report evaluating the structure, the role and operations of the 'troika' (Commission, ECB and the IMF) actions in euro area programme countries'.

--- (2012), 'A Blueprint for a Deep and Genuine Economic and Monetary Union: Launching a European Debate', $\operatorname{COM}(2012) 777$ final $/ 2,30^{\text {th }}$ November (Brussels: European Commission).

European Community (1974), 'Final communiqué of the meeting of heads of government of the Community, Paris, 9-10 Dec. 1974', in Bulletin of the European Communities 12.

European Council (2010), Press release of the Extraordinary Council meeting, Economic and Financial Affairs, Brussels, 9/10 May.

European Court of Auditors (2015), 'Financial assistance provided to countries in difficulties', Special Report 18: http://www.eca.europa.eu/Lists/ECADocuments/SR15 18/SR_CRISIS_SUPPORT_EN.pdf).

European Parliamentary Research Service (2016), 'The European Council and Crisis Management', PE 573.283, February.

European University Institute (EUI) (2014), 'Constitutional Change through Euro Crisis Law: Austria', http://eurocrisislaw.eui.eu.

--- (2014), 'Constitutional Change through Euro Crisis Law: Cyprus', http://eurocrisislaw.eui.eu.

--- (2014), 'Constitutional Change through Euro Crisis Law: France', http://eurocrisislaw.eui.eu.

--- (2014), 'Constitutional Change through Euro Crisis Law: Greece', http://eurocrisislaw.eui.eu.

--- (2014), 'Constitutional Change through Euro Crisis Law: Italy', http://eurocrisislaw.eui.eu.

--- (2014), 'Constitutional Change through Euro Crisis Law: Netherlands', http://eurocrisislaw.eui.eu.

--- (2014), 'Constitutional Change through Euro Crisis Law: Portugal', http://eurocrisislaw.eui.eu.

--- (2014), 'Constitutional Change through Euro Crisis Law: Romania', http://eurocrisislaw.eui.eu.

--- (2014), 'Constitutional Change through Euro Crisis Law: Slovenia', http://eurocrisislaw.eui.eu.

--- (2014), 'Constitutional Change through Euro Crisis Law: Spain', http://eurocrisislaw.eui.eu.

Ferejohn, John and Pasquale Pasquino (2004), 'The Law of Exception: A Typology of Emergency Powers," International Journal of Constitutional Law 2.

Ferrara, Alessandro (2008), The Force of the Example (New York: Columbia UP).

Fischer-Lescano, Andreas (2014), Human Rights in Times of Austerity Policy: The EU Institutions and the Conclusion of Memoranda of Understanding (Baden-Baden: Nomos).

Fontaine, Pascal (1979), 'Jean Monnet's role in the birth of the European Council' (September), translation of Fontaine (1979), 'Le rôle de Jean Monnet dans la genèse du Conseil européen', Revue du Marché commun (Sept.) 229, available at: https://www.cvce.eu/content/publication/2006/12/7/ad29595e-0b0a-49b7-ae65c41c54344a41/publishable en.pdf

Fossum, John Erik and Agustín José Menéndez (2014), The European Union in Crises or the European Union as Crises?, ARENA Report No 2/14 (Oslo: ARENA).

Fraenkel, Ernst (1941 / 1917), The Dual State: A Contribution to the Theory of Dictatorship (Oxford: OUP).

Franceschet, Antonio (2015), 'Theorizing state civil disobedience in international politics', Journal of International Political Theory 11 (2), pp.239-256.

Freeden, Michael (2017), 'After the Brexit Referendum: Revisiting Populism as an Ideology', Journal of Political Ideologies 22 (1), pp.1-11.

Friedman, Milton (1948), ‘A Monetary and Fiscal Framework for Economic Stabilisation', American Economic Review 38, pp.245-64.

Friedrich, Carl (1968), Constitutional Government and Democracy: Theory and Practice in Europe and America (Waltham, Mass: Blaisdell).

Genschel, Philipp and Markus Jachtenfuchs (2018), 'From Market Integration to Core State Powers: The Eurozone Crisis, the Refugee Crisis and Integration Theory', Journal of Common Market Studies 56 (1), pp.178-96.

Georgakakis, Didier (2014), 'À la fois pilote et victime de l'austérité ? Les transformations de l'administration de l'Union européenne sous l'effet de la crise economique et financière', Revue Française d'Administration publique 151-2, pp.805-24. 
--- (2010), 'Do Skills Kill? Les enjeux de la requalification de la compétence des eurofonctionnaires', Revue française d'administration publique 133, pp.61-80.

--- and Jay Rowell (2013), The Field of Eurocracy: Mapping EU actors and professionals (Basingstoke: Palgrave).

Gerber, David J. (1994), 'Constitutionalizing the Economy: German Neo-Liberalism, Competition Law and the "New" Europe', The American Journal of Comparative Law 42 (1), pp.25-84.

Geuna, Marco (2015), 'Machiavelli and the Problem of Dictatorship', Ratio Juris. 28 (2), pp.226-41.

Giddens, Anthony (1990), The Consequences of Modernity (Stanford: SUP).

Goetz, Klaus (2015), 'Synchronisation demokratischen Regierens in der Europäischen Union', Leviathan: Berliner Zeitschrift für Sozialwissenschaft 43 (Sonderband 30), pp.132-51.

---. (2009) 'How does the EU tick? Five propositions on political time', Journal of European Public Policy 16 (2).

Goodin, Robert E. (1998), 'Keeping Political Time: The Rhythms of Democracy', International Political Science Review 19 (1).

Grimm, Dieter (2017), The Constitution of European Democracy (Oxford: OUP).

Gross, Oren (2008), 'Extra-Legality and the Ethic of Political Responsibility', in Victor V. Ramraj (ed.) Emergencies and the Limits of Legality (Cambridge: CUP).

--- (2006), 'What “Emergency” Regime?', Constellations 13 (1).

--- and Fionnuala Ní Aoláin (2006), Law in Times of Crisis: Emergency Powers in Theory and Practice (Cambridge: CUP).

Guyer, Jane (2007), 'Prophecy and the Near Future: Thoughts on macroeconomic, evangelical, and punctuated time', American Ethnologist 34 (3), pp.409-42.

Haas, Ernst B. (1968), The Uniting of Europe: Politics, Social and Economic Forces, 1950-1957 (Stanford: Stanford UP).

Habermas, Jürgen (2015), The Lure of Technocracy, trans. Ciarin Cronin (Cambridge: Polity).

Hall, Stuart and Doreen Massey (2010), 'Interpreting the Crisis', Soundings 44, Spring, pp.57-71.

Hamilton, Alexander, James Madison and John Jay (1787 / 2008), The Federalist Papers (Oxford: OUP).

Hansen, Lene (2012), 'Reconstructing desecuritisation: The normative-political in the Copenhagen School and directions for how to apply it', Review of International Studies 38 (3), pp.525-546.

Harmes, Adam (2006), 'Neoliberalism and multilevel governance', Review of International Political Economy 13 (5), pp.725-749.

Hay, Colin (2004), 'The Normalizing Role of Rationalist Assumptions in the Institutional Embedding of Neoliberalism', Economy and Society 33 (4), pp.500-27.

--- and Ben Rosamond (2002), 'Globalisation, European Integration and the Discursive Construction of Economic Imperatives', Journal of European Public Policy 9 (2), pp.147-67.

Hayek, Friedrich August von (1973), 'Rules and Order', vol. 1 of Law, Legislation and Liberty (London: Routledge \& Kegan Paul).

--- (1955), The Counter-Revolution of Science (New York: Free).

--- (1952), 'The Economic Conditions of Interstate Federalism', in Hayek, Individualism and Economic Order (London: Routledge \& Kegan Paul).

--- (1945), 'The Use of Knowledge in Society', American Economic Review 35, pp.519-30.

Head, Michael (2015), Emergency Powers in Theory and Practice: the long shadow of Carl Schmitt (London: Routledge).

Henning, C Randall (2017), Tangled Governance: International Regime Complexity, the Troika, and the Euro Crisis (Oxford: OUP).

Herman, Lise (2017), 'Democratic Partisanship: From Theoretical Ideal to Empirical Standard', American Political Science Review 111 (4), pp.738-54.

Hien, Josef and Christian Joerges (2017) (eds.) Ordo-Liberalism, Law and the Rule of Economics (Oxford: Hart).

Hirschman, Albert (1996), The Passions and the Interests: Political Arguments for Capitalism Before its Triumph (Princeton: PUP).

Hobolt, Sara B. and James Tilley (2016), 'Fleeing the Centre: the rise of challenger parties in the aftermath of the euro crisis', West European Politics, 39 (5), pp.971-91.

Holmes, Stephen (2009), 'In Case of Emergency: Misunderstanding Tradeoffs in the War on Terror', California Law Review 97 (2).

Hooghe, Lisbet and Gary Marks (2018). 'Cleavage theory meets Europe's crises: Lipset, Rokkan, and the transnational cleavage', Journal of European Public Policy 25 (1), pp.109-135.

--- (2009), 'A Postfunctionalist Theory of European Integration: From Permissive Consensus to Constraining Dissensus', British Journal of Political Science 39 (1), pp.1-23.

Honig, Bonnie (2009), Emergency Politics: Paradox, Law, Democracy (Princeton: PUP).

Imbrogno, Anthony F. (2016) 'The founding of the European Council: economic reform and the mechanism of continuous negotiation', Journal of European Integration 38 (6), pp.719-736.

Innerarity, Daniel (2014), 'Does Europe need a Demos to be Truly Democratic?', LSE Europe in Question Series (LEQS), No. 77. 
Independent Evaluation Office of the IMF (2016), 'The IMF and the Crises in Greece, Ireland and Portugal', $8^{\text {th }}$ July: http://www.ieo-imf.org/ieo/pages/CompletedEvaluation267.aspx).

Invernizzi Accetti, Carlo (2019), What is Christian Democracy? (Cambridge: CUP).

--- and Fabio Wolkenstein (2017), 'The Crisis of Party Democracy, Cognitive Mobilization, and the Case for Making Parties More Deliberative', American Political Science Review 111 (1), pp.97-109

Ipsen, Hans Peter (1970), Verfassungsperspektiven der Europäischen Gemeinschaften (Berlin: de Gruyter).

Isiksel, Turkuler (2016), Europe's Functional Constitution: A Theory of Constitutionalism Beyond the State (Oxford, OUP).

Jacobs, Andreas (2016), 'In Troubled Waters: NATO's new maritime activity in the Aegean', NDC Research Report, Research Division, NATO Defense College 1/16 (March).

Jessop, Bob (2009), 'The Spatio-Temporal Dynamics of Globalising Capital and their Impact on State Power and Democracy', in Rosa and Scheuerman (eds.) High-Speed Society (University Park: Pennsylvania State UP).

Joerges, Christian (2016), 'What is left of the European Economic Constitution II? From Pyrrhic Victory to Cannae Defeat', in Poul F. Kjaer and Niklas Olsen (eds.), Critical Theories of Crisis in Europe: From Weimar to the Euro (Rowman \& Littlefield).

--- (2014a), 'Law and Politics in Europe's Crisis: on the history of the impact of an unfortunate configuration', Constellations 21.

--- (2014b), 'Europe's economic constitution in crisis and the emergence of a new constitutional constellation', in John Erik Fossum and Agustín José Menéndez (2014), The European Union in Crises or the European Union as Crises?, ARENA Report No 2/14 (Oslo: ARENA).

--- (2014c), 'Brother, can you paradigm?', I•CON 12 (3).

--- and Kreuder-Sonnen, Christian (2017), 'European Studies and the European Crisis: Legal and Political Science between Critique and Complacency,' European Law Journal 23 (1-2), pp.118-139.

Johansson, Karl Magnus (2017), 'The Role of Europarties in EU Treaty Reform: Theory and practice', Acta Politica 52 (3), pp.286-305.

Jones, Erik, R. Daniel Kelemen and Sophie Meunier (2016), 'Failing Forward? The Euro Crisis and the Incomplete Nature of European Integration', 49 (7), pp.1010-1034.

Jones, Reece, Corey Johnson, Wendy Brown, Gabriel Popescu, Polly Pallister-Wilkins, Alison Mountz, Emily Gilbert (2017), 'Interventions on the state of sovereignty at the border' Political Geography 59.

Jonsen, Albert R. and Stephen Toulmin (1988), The Abuse of Casuistry: A History of Moral Reasoning (Berkeley: U. of California).

Juncker, Jean-Claude (2015), 'State of the Union 2015: Time for Honesty, Unity and Solidarity', Strasbourg, $9^{\text {th }}$ September 2015: http://europa.eu/rapid/press-release SPEECH-15-5614_en.htm

--- (2014), 'A New Start for Europe: my agenda for jobs, growth, fairness and democratic change', Opening Statement in the European Parliament Plenary Session, $15^{\text {th }}$ July:

http://www.eesc.europa.eu/resources/docs/jean-claude-juncker---political-guidelines.pdf.

Kaelble, Hartmut (2014), 'Eine beispiellose Krise? Die Krise der europäischen Integration seit $2010 \mathrm{im}$ historischen Vergleich', in M. Heidenreich (ed.) Krise der europaischen Vergesellschaftung? (Wiesbaden: Springer).

Kaiser, Wolfram (2007), Christian Democracy and the Origins of European Union (Cambridge: CUP).

Kalyvas, Andreas (2008), Democracy and the Politics of the Extraordinary: Max Weber, Carl Schmitt, and Hannah Arendt (Cambridge: CUP).

--- (2007), 'The Tyranny of Dictatorship: when the Greek tyrant met the Roman dictator', Political Theory 35.

Katz, Richard, and Peter Mair (2009), 'The Cartel Party Thesis', Perspectives on Politics 7 (4).

Kauppi, Niilo (2014), 'Knowledge Warfare: Social Scientists as Operators of Global Governance', International Political Sociology 8 (3), pp.330-2.

Kauppi, Niilo and Mikael R. Madsen (2013) (eds.), Transnational Power Elites: The new professionals of governance, law and security (London: Routledge).

--- (2014), 'Fields of Global Governance: How Transnational Power Elites Can Make Global Governance Intelligible', International Political Sociology 8 (3), pp.324-30.

Kelly, Duncan (2017), 'Populism and the History of Popular Sovereignty, in Cristobal Rovira Kaltwasser, Paul Taggart, Paulina Ochoa Espejo, and Pierre Ostiguy (eds.) The Oxford Handbook of Populism (Oxford: OUP).

--- (2017), 'Carl Schmitt's Political Theory of Dictatorship', in Jens Meierhenrich and Oliver Simons (eds.) Oxford Handbook of Carl Schmitt (Oxford: OUP).

Kennedy, David (2016) A World of Struggle: How Power, Law and Expertise shape Global Political Economy (Princeton: PUP).

Kilpatrick, Claire (2015), 'On the Rule of Law and Economic Emergency: The Degradation of Basic Legal Values in Europe's Bailout', Oxford Journal of Legal Studies 35, pp.325-53.

Kincaid, G. Russell (2016), 'The IMF's Role in the Euro Area Crisis: What are the Lessons from the IMF's Participation in the Troika?', Independent Evaluation Office of the IMF, Background paper BP/16-02/06.

Kinski, Lucy (2018), 'Whom to Represent? National Parliamentary Representation during the Eurozone Crisis', Journal of European Public Policy 25 (3).

Kjaer, Poul (2017), 'European crises of legally-constituted public power: From the "law of corporatism" to the 
"law of governance", European Law Journal 23 (5), pp.417-30.

Klein, Naomi (2017), No is Not Enough: Defeating the new Shock Politics (London: Allen Lane).

--- (2007), The Shock Doctrine: The Rise of Disaster Capitalism (London: Penguin).

Klieman, Aaron (1976), 'Emergency Politics: the Growth of Crisis Government', Conflict Studies 70, April.

Koselleck, Reinhart (2004), Futures Past: on the semantics of historical time (New York: Columbia UP).

Kozicharow, Nicola (2011), 'Filipp Maliavin's Troika Dream of 1933', paper presented at Cambridge University, 15 February.

Krebs, Ronald (2009), 'In the Shadow of War: The Effects of Conflict on Liberal Democracy', International Organization 63 (1), pp.177-210.

Kreuder-Sonnen, Christian (2018), 'An Authoritarian Turn in Europe and European Studies?', Journal of European Public Policy 25 (3), pp.452-64.

--- (2018), 'Political Secrecy in Europe: crisis management and crisis exploitation', West European Politics 14 (4), pp.958-80.

--- (2016), 'Beyond integration theory: the (anti-)constitutional dimension of European crisis governance', Journal of Common Market Studies 54 (6), pp.1350-66.

Kühnhardt, Ludger (ed.) (2009) Crises in European Integration: Challenges and responses, 1945-2005 (Oxford: Berghahn).

Kumm, Mathias (2012), 'Constitutionalism and the Moral Point of Constitutional Pluralism: Institutional Civil Disobedience and Conscientious Objection', in Julie Dickson and Pavlos Eleftheriades (eds.) Philosophical Foundations of EU Law (Oxford: OUP).

Kydland, Finn E. and Edward C. Prescott (1977), 'Rules rather than discretion: the inconsistency of optimal plans', Journal of Political Economy 85 (3).

Lacey, Joseph (2017), Centripetal Democracy: Democratic Legitimacy and Political Identity in Belgium, Switzerland and the European Union (Oxford: OUP).

Laffan, Brigid and Pierre Schlosser (2016), 'Public finances in Europe: fortifying EU economic governance in the shadow of the crisis', Journal of European Integration 38 (3).

Lakoff, Andrew (2007), 'Preparing for the next emergency', Public Culture 19 (2): 247-271.

Langenohl, Andreas (2017), 'Securities markets and political securitization: The case of the sovereign debt crisis in the Eurozone', Security Dialogue 48 (2), pp.131-148.

Lapavitsas, Costas (2012), Crisis in the Eurozone (London: Verso).

Lara, María Pía (2008), 'Reflective judgment as world disclosure', Philosophy and Social Criticism 34 (1-2), pp.83-100.

Laux, Henning and Rosa, Hartmut (2015), 'Clockwork Politics. Fünf Dimensionen politischer Zeit', Leviathan: Berliner Zeitschrift für Sozialwissenschaft 43 (Sonderband 30), pp.52-70.

Lazar, Nomi Claire (2009), States of Emergency in Liberal Democracies (Cambridge: CUP).

Lemke, Matthias (2018), 'What does state of exception mean? A definitional and analytical approach', Zeitschrift für Politikwissenschaft 3 (online early).

Lemoine, Benjamin (2017), 'Measuring and Restructuring the State: Debt Metrics and the Control of Present and Future Political Order' in King, Desmond and Patrick Le Gales (2017), Reconfiguring European States in Crisis (Oxford: OUP).

Lewis, Jeffrey (2015), 'The Council of the European Union and the European Council', in José M. Magone (ed.) Routledge Handbook of EU Studies (Abingdon: Routledge).

Levine, Caroline (2014), Forms: Whole, Rhythm, Hierarchy, Network (Princeton: PUP).

Lincott, Andrew (2003), The Constitution of the Roman Republic (Oxford: OUP).

Linz, Juan J. (1998), 'Democracy's Time Constraints', International Political Science Review 19 (1), pp.19-37.

Lokdam, Hjalte (in preparation), PhD thesis (London: LSE).

Lorimer, Marta (in preparation), Far Right Parties and Europe, PhD thesis (London: LSE).

Machiavelli, Niccolò (2008 / 1531), Discourses on Livy, trans. Julia Conaway Bondanella and Peter Bondanella (Oxford: OUP).

Mckenzie, Lisa (2017), 'The Class Politics of Prejudice: Brexit and the land of no-hope and glory', British Journal of Sociology 68 (S1).

MacCormick, Neil (1999), Questioning Sovereignty: Law, State, and Nation in the European Commonwealth (Oxford, OUP).

Mair, Peter (2013), Ruling the Void: The Hollowing of Western Democracy (London: Verso).

--- (2007) 'Political opposition and the European Union', Government \& Opposition 41 (1), pp.1-17.

Majone, Giandomenico (1996), 'Temporal Consistency and Policy Credibility: Why Democracies Need NonMajoritarian Institutions', European University Institute, Working Paper RSC No 96/57.

Mandel, Ernest (1974), 'EEC: The Common Market in Crisis' Inprecor 2 (June 20) pp.14-18.

Manin, Bernard (2008), 'The Emergency Paradigm and the New Terrorism: What if the end of terrorism was not in sight?' in Sandrine Baume and Biancamaria Fontana (eds.), Les usages de la séparation des pouvoirs (Paris: Michel Houdiard), pp.136-171.

Marcussen, Martin (2009), 'Scientization of Central Banking: The Politics of A-Politicization,' in Kenneth Dyson and Martin Marcussen (eds.), Central Banks in the Age of Euro: Europeanization, Convergence and Power 
(Oxford: OUP), pp.373-390.

Matthijs, Matthias (2016), 'Powerful rules governing the euro: the perverse logic of German ideas', Journal of European Public Policy, 23 (3), pp.375-91.

Menendez, Agustin (2017), 'The Crisis of Law and the European Crises: From the Social and Democratic Rechtsstaat to the Consolidating State of (Pseudo-)technocratic Governance', Journal of Law and Society 44 (1), pp.56-78.

--- (2016) 'The Refugee Crisis: Between Human Tragedy and Symptom of the Structural Crisis of European Integration', European Law Journal 22 (4), pp.388-416.

--- (2013), 'The Existential Crisis of the European Union', German Law Journal 14 (5), pp.453-526.

Mills, C. Wright (1956 / 2000), The Power Elite (Oxford: OUP), Chap. 1, 'The Higher Circles'.

Milstein, Brian (2015), 'Thinking politically about crisis: A pragmatist perspective', European Journal of Political Theory 14 (2), pp.141-60.

Milward, Alan (1992), The European Rescue of the Nation-State (London: Routledge).

Mischner, Sabine (2018, online early), 'The Temporalities of Exception. The long shadow of the American Civil War', Zeitschrift für Politikwissenschaft 3.

Mitrany, David (1941/1975), 'A War-Time Submission', in The Functional Theory of Politics (London: Martin Robertson).

Mody, Ashoka (2018), EuroTragedy: A Drama in Nine Acts (Oxford: OUP).

Moffitt, Benjamin (2016), The Global Rise of Populism: Performance, Political Style, and Representation (Stanford: SUP).

Monnet, Jean (1978), Memoirs, trans. Richard Mayne (London: Collins).

Moravcsik, Andrew (1998), The Choice for Europe: Social Purpose and State Power from Messina to Maastricht (Ithaca: Cornell UP).

Mouffe, Chantal (2005), On the Political (London: Routledge).

Mourlon-Druol, Emmanuel (2016), 'Steering Europe: Explaining the Rise of the European Council, 1975-1986', Contemporary European History 25 (3), pp.409-37.

--- (2012). "Managing from the Top: Globalisation and the Rise of Regular Summitry, Mid-1970s-early 1980s", Diplomacy and Statecraft 23:4, pp.679-703.

--- (2010), 'Filling the EEC Leadership Vacuum? The Creation of the European Council in 1974', Cold War History 10 (3).

--- (2010), 'The Victory of the Intergovernmental Method? The emergence of the European Council in the Community's institutional set-up (1974-77)', in Daniela Preda, Daniele Pasquinucci (eds), The Road Europe Travelled Along: The Evolution of the EEC/EU Institutions (Brussels: Peter Lang).

Moury, Catherine and Adam Standring (2017), "Going beyond the Troika": Power and discourse in Portuguese austerity politics', European Journal of Political Research 56 (3).

Mudde, Cas (2004), 'The Populist Zeitgeist,' Government and Opposition, 39 (3), pp.541-63.

--- and Cristobal Rovira Kaltwasser (2017), Populism: A Very Short Introduction (Oxford: OUP).

Mudge, Stephanie (2018), Leftism Reinvented: Western Parties from Socialism to Neoliberalism (Cambridge MA: Harvard UP).

Mudge, Stephanie and Antoine Vauchez (2016), 'Fielding Supranational: The ECB hyper-scientization as a field effect', Sociological Review 64 (2).

--- (2012), 'Building Europe on a Weak Field: Law, Economics, and Scholarly Avatars in Transnational Politics', American Journal of Sociology 118 (2), pp.449-492.

Müller, Jan-Werner (2016), What is Populism? (Philadelphia: University of Pennsylvania Press).

NEON, NEF, FrameWorks Institute, PIRC (2018), Framing the Economy: How to win the case for a better system (London).

Niemann, Arne and Natascha Zaun (2018), 'EU Refugee Policies and Politics in Times of Crisis: Theoretical and Empirical Perspectives', Journal of Common Market Studies 56 (1), pp.3-22.

Niemann, Arne and Johanna Speyer (2018), 'A Neofunctionalist Perspective on the "European Refugee Crisis": The Case of the European Border and Coast Guard', Journal of Common Market Studies 56 (1), pp.23-43.

Niesen, Peter (in press), 'Reframing civil disobedience: Constituent power as a language of transnational protest', Journal of International Political Theory.

Nippel, Wilfried (2012), 'Saving the Constitution: the European discourse on dictatorship', in Janet Coleman and Paschalis M. Kitromilides In the Footsteps of Herodotus: Towards European Political Thought (Florence: Leo S. Olschki), pp.29-50.

Noelle-Neumann, Elizabeth (1984), The Spiral of Silence: Public Opinion - Our Social Skin (Chicago: UCP).

Ochoa Espejo, Paulina (2017), 'Populism and the Idea of the People', in Cristobal Rovira Kaltwasser, Paul Taggart, Paulina Ochoa Espejo and Pierre Ostiguy (eds.) The Oxford Handbook of Populism (Oxford: OUP).

Offe, Claus (2015), 'Temporalstrukturen sozialer Macht', Leviathan: Berliner Zeitschrift für Sozialwissenschaft 43 (Sonderband 30), pp.29-51.

--- (2014), Europe Entrapped (Cambridge: Polity).

--- (2009), 'Governance: An “Empty Signifier”?', Constellations 16 (4).

Olson, Richard G. (2015), Scientism and Technocracy in the Twentieth Century: the legacy of scientific 
management (Lanham: Rowman \& Littlefield).

Olsson, E.-K. and K. Hammargård (2016), 'The rhetoric of the President of the European Commission: charismatic leader or neutral mediator?' Journal of European Public Policy 23 (4): 550-70.

Opitz, Sven and Ute Tellmann (2015), 'Future Emergencies: Temporal Politics in Law and Economy', Theory, Culture and Society 32 (2).

Orr, Graeme (2015), Ritual and Rhythm in Electoral Systems: A Comparative Legal Account (Farnham: Ashgate).

Pansardi, Pamela and Pier Domenico Tortola (2018), 'The charismatic leadership of the ECB presidency: A language-based analysis', European Journal of Political Research, online early.

Pansardi, Pamela and Francesco Battegazzorre (2018): 'The Discursive Legitimation Strategies of the President of the Commission: a qualitative content analysis of the State of the Union Addresses (SOTEU), Journal of European Integration, online early.

Patberg, Markus (in press), 'Destituent Power in the European Union: On the limits of a negativistic logic of constitutional politics', Journal of International Political Theory 15 (1).

--- (in preparation), 'Extraordinary Partisanship in the European Union: Constituent Power and the Problem of Political Agency'.

Paudyn, Bartholomew (2013), 'Credit rating agencies and the sovereign debt crisis: performing the politics of creditworthiness through risk and uncertainty', Review of International Political Economy, 20 (4). pp.788-818.

Picon, Antoine (2007), 'French Engineers and Social Thought, 18-20 ${ }^{\text {th }}$ Centuries: An Archeology of Technocratic Ideals', History and Technology 23 (3), pp.197-208.

Posner, Eric A. and Adrian Vermeule (2011), The Executive Unbound: After the Madisonian Republic (Oxford: OUP).

Pound, Roscoe (1913), ‘Justice According to Law', Columbia Law Review, 13 (8), pp. 696-713.

Preuß, Ulrich K. (2017), 'Die Krise der Europäischen Union als Ausnahmezustand?', KJ Kritische Justiz 50, pp.51-67.

Putnam, Robert (1977), 'Elite Transformation in Advanced Industrial Societies: An Empirical Assessment of the Theory of Technocracy', Comparative Political Studies 10 (3), pp.383-412.

Radaelli, Claudio (1999), Technocracy in the European Union (London: Routledge).

Raithby, John (ed.) (1819), Statutes of the Realm: Volume 5, 1628-80 (British History online).

Ramraj Victor V. (ed.) (2008), Emergencies and the Limits of Legality (Cambridge: CUP).

Rawls, John (1999 [1971]), A Theory of Justice (Cambridge MA: Harvard UP).

Reckwitz, Andreas (2017), Die Gesellschaft der Singularitäten - Zum Strukturwandel der Moderne (Berlin: Suhrkamp).

Rehn, Olli and Jörg Asmussen (2012), 'Responses to Written Questions on the Economic and Social Crisis in Greece by Several Political Groups within the European Parliament', $23^{\text {rd }}$ March.

Reinhart, Carmen and Kenneth Rogoff (2009), This Time is Different: Eight Centuries of Financial Folly (Princeton: PUP).

Riescher, Gisela (1994), Zeit und Politik: Zur institutionellen Bedeutung von Zeitstrukturen in parlamentarischen und präsidentiellen Regierungssystemen (Baden-Baden: Nomos).

Riker, William (1986), The Art of Political Manipulation (New Haven: Yale UP).

Rittberger, Berthold (2014), 'Integration without Representation? The European Parliament and the Reform of Economic Governance in the EU', Journal of Common Market Studies 52 (6), 1174-1183.

Roberts, Kenneth M. (2017), 'Populism and Political Parties', in Rovira Kaltwasser, Taggart, Ochoa Espejo, and Ostiguy (eds.) The Oxford Handbook of Populism (Oxford: OUP).

Rödl, Florian (2012), 'EU im Notstandsmodus', Blätter für Deutsche und Internationale Politik 5 (5) (https://www.blaetter.de/archiv/jahrgaenge/2012/mai/eu-im-notstandsmodus),

Rosa, Hartmut (2013), Social Acceleration: A New Theory of Modernity (New York: Columbia UP).

--- and Scheuerman, William (eds.) (2009), High-Speed Society (University Park: Pennsylvania State UP).

Rosenboim, Or (2017), The Emergence of Globalism: Visions of World Order in Britain and the United States, 1939-1950 (Princeton: PUP).

Rossiter, Clinton (1948), Constitutional Dictatorship: Crisis Government in the Modern Democracies (Princeton: PUP).

Rovira Kaltwasser, Cristobal, Paul Taggart, Paulina Ochoa Espejo, and Pierre Ostiguy (2017), 'Populism: An Overview of the Concept and the State of the Art', in Rovira Kaltwasser, Taggart, Ochoa Espejo, and Ostiguy (eds.) The Oxford Handbook of Populism (Oxford: OUP).

Rüb, Friedbert W. (2015), 'Die Zeit und die Unzeit der Politik', Leviathan: Berliner Zeitschrift für Sozialwissenschaft 43 (Sonderband 30), pp.195-217.

Rubenstein, Jennifer (2015), 'Emergency Claims and Democratic Action', Social Philosophy and Politics 32 (1), pp.101-26.

Ruiz-Rufino, Rubén and Sonia Alonso (2017), 'Democracy without choice: Citizens' perceptions of government autonomy during the Eurozone crisis', European Journal of Political Research 56, pp.320-345.

Rummens, Stefan (2017), 'Populism as a Threat to Liberal Democracy', in Rovira Kaltwasser, Taggart, Ochoa Espejo, and Ostiguy (eds.) The Oxford Handbook of Populism (Oxford: OUP).

Ryle, Gilbert (1949), 'Knowing How and Knowing That', in Gilbert Ryle: Collected Papers, vol. 2. (New York: 
Barnes and Noble).

Sanchez-Cuenca, Ignacio (2017), 'From a Deficit of Democracy to a Technocratic Order: The Postcrisis Debate on Europe', Annual Review of Political Science 20, pp.351-69.

Sandbu, Martin (2015), Europe's Orphan: the future of the euro and the politics of debt (Princeton: PUP).

Schäfer, David (2016), 'A Banking Union of Ideas? The Impact of Ordoliberalism and the Vicious Circle on the EU Banking Union', Journal of Common Market Studies 54 (4), pp.961-80.

Scharpf, Fritz (2014), 'Political Legitimacy in a Non-optimal Currency Area', in Sara Hobolt and Olaf Cramme (eds), Democratic Politics in a European Union under Stress (Oxford: OUP).

--- (2006), 'The joint decision trap revisited', Journal of Common Market Studies 44 (4).

--- (1999), Governing in Europe: Effective and Democratic? (Oxford: OUP).

Schäuble, Wolfgang (2011), 'We can only achieve a political union if we have a crisis', New York Times, 18 November (http://www.nytimes.com/2011/11/19/world/europe/for-wolfgang-schauble-seeing-opportunity-ineuropes-crisis.html).

Schedler, Andreas and Javier Santiso (1998), 'Democracy and time: an invitation', International Political Science Review 19 (1), pp.5-18.

Schelkle, Waltraud (2017), The Political Economy of Monetary Stability: Understanding the Euro Experiment (Oxford: OUP).

Scheppele, Kim Lane (2018), ‘Autocratic Legalism', University of Chicago Law Review 85 (2), pp.545-83.

--- (2012), ‘The New Judicial Deference', Boston University Law Review 92, pp.89-170.

--- (2010), 'Exceptions that Prove the Rule: Embedding emergency governing in everyday constitutional life', in J. K. Tulis and S. Macedo (eds), The Limits of Constitutional Democracy (Princeton: PUP).

Scheuerman, William (2019), 'Constituent Power and Civil Disobedience: Beyond the Nation State?' Journal of International Political Theory 15 (1).

--- (2018) Key Concepts: Civil Disobedience (Cambridge: Polity).

--- (2017a), 'Die Globalisierung von Carl Schmitt?', KJ Kritische Justiz 50, pp.30-37.

--- (2017b), 'States of Emergency', in Jens Meierhenrich and Oliver Simons (eds.) Oxford Handbook of Carl Schmitt (Oxford: OUP).

--- (2016), 'Crises and Extra-Legality: From Above and from Below', in Poul F. Kjaer and Niklas Olsen (eds.), Critical Theories of Crisis in Europe: From Weimar to the Euro (Rowman \& Littlefield).

--- (2015), 'Recent Theories of Civil Disobedience: An Anti-Legal Turn?', Journal of Political Philosophy 23 (4).

--- (2006), 'Survey Article: Emergency Powers and the Rule of Law After 9/11', Journal of Political Philosophy, 14 (1), pp.61-84.

--- (2004), Liberal Democracy and the Social Acceleration of Time (Baltimore: Johns Hopkins UP).

--- (1999), “The Economic State of Emergency," Cardozo Law Review 21 (5-6).

Schimmelfennig, Frank (2018), 'European integration (theory) in times of crisis: A comparison of the euro and Schengen crises', Journal of European Public Policy, 25 (7), pp.969-89.

Schmidt, Vivien (2018), 'Rethinking EU Governance: From 'Old' to 'New' Approaches to Who Steers Integration', Journal of Common Market Studies 56 (7).

Schmitt, Carl (2005), Political Theology: Four Chapters on the Concept of Sovereignty (Chicago: Chicago UP).

--- (2013 [1921]), Dictatorship (Cambridge: Polity).

--- (1928 / 2008), Constitutional Theory (Durham NC: Duke UP).

Schmitter, Philippe C. (2004) 'Neo-neo-functionalism?', in A. Wiener and T. Diez (eds), European Integration Theory (Oxford: OUP), pp.45-74.

--- (1971) 'A revised theory of regional integration', in L.N. Lindberg and S.A. Scheingold (eds), Regional Integration: Theory and Research (Cambridge, MA: Harvard UP), pp.232-64.

Scicluna, Nicole (2018), 'Integration through the disintegration of law? The ECB and EU constitutionalism in the crisis', Journal of European Public Policy 25 (12).

--- (2015), European Union Constitutionalism in Crisis (London: Routledge).

--- (2014), 'Politicization without democratization: How the Eurozone crisis is transforming EU law and politics', International Journal of Constitutional Law 12 (3), pp.545-71.

Scipioni, Marco (2018), 'Failing forward in EU migration policy? EU integration after the 2015 asylum and migration crisis', Journal of European Public Policy 28 (9)

--- (2018), 'De Novo Bodies and EU Integration: What is the Story behind EU Agencies' Expansion?', Journal of Common Market Studies 56 (4), pp.768-784.

Seabrooke, Leonard (2014), 'Identity Switching and Transnational Professionals', International Political Sociology 8 (3), pp.335-7.

Seikel, Daniel (2016), 'Flexible Austerity and Supranational Autonomy: The Reformed Excessive Deficit Procedure and the Asymmetry between Liberalization and Social Regulation in the EU', Journal of Common Market Studies 54 (6), pp.1398-1416.

Sending, Ole Jacob (2014), 'The International Civil Servant', International Political Sociology 8 (3), pp.338-40.

Seville, Astrid (2017), “There is No Alternative”: Politik zwischen Demokratie und Sachzwang (Frankfurt am Main: Campus). 
Slobodian, Quinn (2018), Globalists: The End of Empire and the Birth of Neoliberalism (Cambridge MA: Harvard UP).

Smith, Alastair (2004), Electoral Timing (Cambridge: CUP).

Snyder, Timothy (2010), Bloodlands: Europe Between Hitler and Stalin (New York: Basic Books).

Sorell, Tom (2013), Emergencies and Politics: A Sober Hobbesian Approach (Cambridge: CUP).

Spinelli, Altiero and Ernesto Rossi (1941), 'The Manifesto of Ventotene for a Free and United Europe' (https://www.cvce.eu/content/publication/1997/10/13/316aa96c-e7ff-4b9e-b43a958e96afbecc/publishable en.pdf

Stavrakakis, Yannis, Giorgos Katsambekis, Alexandros Kioupkiolis, Nikos Nikisianis and Thomas Siomos (2018), 'Populism, anti-populism and crisis', Contemporary Political Theory 17 (1), pp.4-27.

Storey, Andy (2019), 'Authoritarian Neoliberalism in Europe: The Red Herring of Ordoliberalism', Critical Sociology (online early).

Streeck, Wolfgang (2016), How Will Capitalism End (London: Verso).

--- (2014), 'The Politics of Public Debt: Neoliberalism, Capitalist Development and the Restructuring of the State', German Economic Review 15 (1), pp.143-165.

--- (2013), Gekaufte Zeit. Die vertagte Krise des demokratischen Kapitalismus (Berlin: Suhrkamp).

Sunstein, Cass (1996), Legal Reasoning and Political Conflict (OUP).

Suntrup, Jan (2018), 'From Emergency Politics to Authoritarian Constitutionalism? The Legal and Political Costs of EU Financial Crisis Management', German Law Journal 19 (2).

Tamanaha, Brian Z. (2004), On the Rule of Law: History, Politics, Theory (Cambridge: CUP).

Teitel, Ruti (1997), 'Transitional Jurisprudence: The Role of Law in Political Transformation', Yale Law Journal 106.

Thompson, Dennis (2004), 'Election Time: Normative Implications of Temporal Properties of the Electoral Process in the United States', American Political Science Review 98 (1).

Tooze, Adam (2018), Crashed: How a Decade of Financial Crises Changed the World (London: Penguin).

Tsipras, Alexis, 1 July 2015: http://www.primeminister.gov.gr/english/2015/07/01/prime-minister-alexis-tsiprasmessage/.

--- 28 June 2015: http://www.primeminister.gov.gr/english/2015/06/28/prime-minister-alexis-tsipras-statementconcerning-on-the-latest-developments/

Tucker, Paul (2018), Unelected Power: the quest for legitimacy in central banking and the regulatory state (Princeton: PUP).

Tuori, Kaarlo and Klaus Tuori (2014), The Eurozone Crisis: A Constitutional Analysis (Cambridge: CUP).

Turner, Stephen (2014), The Politics of Expertise (London: Routledge).

--- (2001), 'What is the Problem with Experts?', Social Studies of Science 31 (1), pp. 123-149.

Tushnet, Mark (2005), 'Emergencies and the Idea of Constitutionalism', in Tushnet (ed.) The Constitution in Wartime: Beyond Alarmism and Complacency (Durham NC: Duke UP).

UNHCR (2015), 'Over One Million Sea Arrivals Reach Europe in 2015', $30^{\text {th }}$ Dec.: http://www.unhcr.org/afr/news/latest/2015/12/5683d0b56/million-sea-arrivals-reach-europe-2015.html

van Middelaar, Luuk (2019), Alarums and Excursions: Improvising politics on the European stage (Newcastle: Agenda).

Van Rompuy, Herman, with José Manuel Barroso, Jean-Claude Juncker and Mario Draghi (2012), 'Towards a Genuine Economic and Monetary Union' ['Four Presidents' Report'] (Brussels: Council).

Van 't Klooster, Jens (2018), 'Democracy and the European Central Bank's Emergency Powers' Midwest Studies in Philosophy XLII.

Vanberg, Viktor J. (2004), ‘The Freiburg School: Walter Eucken and Ordoliberalism', Paper 04/11 (Freiburg: Walter Eucken Institut).

Varoufakis, Yanis (2017), Adults in the room: my battle with Europe's deep establishment (London: Penguin).

--- (2016), 'Europe's Left after Brexit', ${ }^{\text {th }}$ September (https://yanisvaroufakis.eu/2016/09/08/europes-left-afterbrexit).

Vauchez, Antoine (2016), Democratizing Europe (Basingstoke: Palgrave Macmillan).

--- (2015), Brokering Europe. Euro-lawyers and the Making of a Transnational Polity (Cambridge: CUP).

--- (2008) 'The Force of a Weak Field: Law and Lawyers in the Government of the European Union', International Political Sociology 2 (2), pp.128-44.

Vogl, Joseph (2016), The Ascendancy of Finance (Cambridge: Polity).

Wagner, Rikke (2015), 'Transnational civil dis/obedience' in the Danish family unification dispute', European Political Science Review 7 (1), pp.43-62.

Watson, Matthew and Colin Hay (2004), 'The Discourse of Globalization and the Logic of No Alternative: Rendering the Contingent Necessary in the Political Economy of New Labour', Policy and Politics, 30 (4), pp.289-305.

Weber, Max (1968), 'The Nature of Charismatic Authority and its Routinization', in S. N. Eisenstadt (ed.) Max Weber on Charisma and Institution Building: Selected Papers (Chicago: UCP).

Weiler, J.H.H. (2012), 'Integration through Fear', European Journal of International Law, 23 (1) pp.1-5.

Wessels, Wolfgang (2015), The European Council (Basingstoke: Palgrave Macmillan), 
White, Jonathan (2017a), 'Between Rules and Discretion: Thoughts on Ordo-Liberalism', in Josef Hien and Christian Joerges (eds.) Ordo-Liberalism, Law and the Rule of Economics (Oxford: Hart).

White, Jonathan (2017b), 'Revisionism as a Logic of Institutional Change', European Law Journal 23 (5), pp.406-416.

White, Jonathan (2015), 'Emergency Europe' Political Studies 63 (2), pp.300-18.

White, Jonathan (2014), 'Politicizing Europe: The Challenge of Executive Discretion', in Sara Hobolt and Olaf Cramme (eds), Democratic Politics in a European Union under Stress (Oxford: OUP).

White, Jonathan (2013), 'Left and Right in the Economic Crisis', Journal of Political Ideologies 18 (2), pp.150-70.

White, Jonathan (2011), Political Allegiance after European Integration (Basingstoke: Palgrave MacMillan).

White, Jonathan (2010a), 'Europe and the Common', Political Studies 58 (1), pp.104-22.

White, Jonathan (2010b), 'The Politics of Other Citizens', Citizenship Studies 14 (4), pp.411-427.

White, Jonathan (2010c), 'Responding to Norm Indeterminacy Outside the Nation-State Frame', Comparative Sociology 9 (5), pp.611-630.

White, Jonathan and Lea Ypi (2016), The Meaning of Partisanship (Oxford: OUP).

Wolkenstein, Fabio (2018a), 'Demoicracy, Transnational Partisanship and the EU', Journal of Common Market Studies 56 (2), pp.284-299.

--- (2018b), 'Transnational Partisanship and Networked Constituent Power in the EU', LEQS Paper No. 138/2018.

--- (2016), 'A Deliberative Model of Intra-Party Democracy', Journal of Political Philosophy 24 (3), pp.297-320.

Woodruff, David M. (2016), 'Governing by Panic: The Politics of the Eurozone Crisis', Politics \& Society 44 (1), pp.81-116.

Zerubavel, Evitar (1985), Hidden Rhythms: Schedules and Calendars in Social Life (Berkeley: UCP).

Zhukov, Yuri (2016), 'NATO's Mediterranean Mission: What the Alliance is Doing in the Aegean Sea', Foreign Affairs 21 February. 